\title{
A Simple and Sensitive Spectrophotometric Determination of Monoamine Oxidase Activity1)
}

\author{
By W. Christ, Dagmar Rakow, M. Fernandes and S. Magour \\ Institut für Neuropsychopharmakologie der Freien Universität Berlin
}

(Eingegangen am 9. Mai 1973)

\begin{abstract}
A simple, sensitive spectrophotometric determination of monoamine oxidase activity from tissue homogenates is described. This method is based on the high extinction coefficient of 4-hydroxy-3-methoxy-benzaldehyde (vanillin) at $345 \mathrm{~nm}$ at $\mathrm{pH} \sim 11.7$. Vanillin is formed by monoamine oxidase when 4-hydroxy-3-methoxy-benzylamine is used as substrate. The primary oxidation product, 4-hydroxy-3-methoxybenzaldehyde, is not further metabolized by aldehyde reductase or aldehyde dehydrogenase.

The apparent $\mathrm{K}_{\mathrm{m}}$ value of 4-hydroxy-3-methoxy-benzylamine for monoamine oxidase of rat brain is 150 to $180 \mu \mathrm{mol} / \mathrm{l}$ (pH 7.0 ). The $\mathrm{pH}$ optimum of the rat brain monoamine oxidase with this substrate was found to be at about 9.0. Inhibition of monoamine oxidase of rat brain after pretreatment of rats with iproniazid, pargyline and tranylcypromine was investigated with this method. The data were analyzed according to LINEWEAVER and BuRK.
\end{abstract}

Eine einfache, empfindliche und schnelle spektrophotometrische Bestimmungsmethode der Monoamin-Oxidase-Aktivität in Gewebehomogenaten wird beschrieben. Die Methode beruht auf dem hohen Extinktionskoeffizienten von 4-Hydroxy-3-methoxy-benzaldehyd (Vanillin) bei $345 \mathrm{~nm}$ und bei einem pH von 11,7. Dieser Aldehyd entsteht, wenn man der Monoamin-Oxidase 4-Hydroxy-3-methoxybenzylamin als Substrat anbietet. Vanillin wird weder durch die Aldehyd-Reduktase noch durch die Aldehyd-Dehydrogenase weiter metabolisiert.

Der scheinbare $\mathrm{K}_{\mathrm{m}}$-Wert des 4-Hydroxy-3-methoxy-benzylamins liegt für dic Monoamin-Oxidase aus Rattengehirn bei 150 -180 $\mu$ mol/1 $(\mathrm{pH} 7,0)$ und das $\mathrm{pH}$ Optimum liegt für dieses Substrat bei etwa 9,0.

Es wurde die Hemmung der Monoamin-Oxidase-Aktivität des Rattengehirns nach in vitro-Vorbehandlung der Ratten mit MonoaminOxidase-Inhibitoren wie Iproniazid, Pargylin und Tranylcypromin mit dieser Methode untersucht. Die Ergebnisse wurden in LiNeWEAVER-BURK-Diagrammen ausgewertet.

Monoamine oxidase (MAO) [monoamine: $\mathrm{O}_{2}$ oxidoreductase (deaminating) EC 1.4.3.4] catalyzes the oxidative deamination of a great variety of monoamines. The aldehydes originating from this reaction are then either reduced by aldehyde reductase ${ }^{2}$ ) (EC 1.1.1.2) to the corresponding alcohol or oxidized by aldehyde dehydrogenase (EC 1.2.1.3) to carbonic acids. The possibility cannot be excluded that these reactionproducts might interfere with some of the methods used for the determination of monoamine oxidase activity. Most methods for the estimation of monoamine oxidase are based on the measurement of oxygen consumption or the determination of substrate disappearance by spectrophotometric and fluorometric methods (1). More recently radiometric procedures have been introduced using e. g. ${ }^{14} \mathrm{C}$-tyramine and ${ }^{14} \mathrm{C}$-tryptamine as substrates (1).

The method presented in this paper is based on the high absorption of 4-hydroxy-3-methoxy-benzaldehyde (vanillin) at $345 \mathrm{~nm}$ at $\mathrm{pH} \sim 11.7$. This aldehyde is formed when monoamine oxidase acts on 4-hydroxy3-methoxy-benzylamine as substrate.

1) A preliminary report of this study was presented at the 14 th Frühjahrstagung der Deutschen Pharmakologischen Gesellschaft in Mainz, 1973 (12).

2) Enzyme: NADPH-linked aldehyde reductase (alcohol: NADP oxidoreductase EC 1.1.1.2).

\section{Material and Methods}

\section{Substances}

4-Hydroxy-3-methoxy-benzylamine $\cdot \mathrm{HCl}$; 4-hydroxy-3-methoxybenzaldehyde (vanillin) and 4-hydroxy-3-methoxy-benzoic acid (vanillic acid) werc purchased from EGA-Chemie, 7924 Steinheim, Germany.

Iproniazid (Marsilid) and Pargyline $\cdot \mathrm{HCl}$ were gifts of HoffmannLa Roche AG, Basel, Switzerland and of Abbott Laboratories, North Chicago, Illinois, USA, respectively.

Tranylcypromine and Harmaline $\mathrm{HCl}$ were obtained from Sigma, St. Louis, Missouri, USA; D-Amphetamine-sulphate and 4nitrobenzaldehyde were supplied by E. Merck AG, Darmstadt, Germany. All substances mentioned were used without further purification with the exception of vanillic acid, which was recrystallized from hot water.

\section{Thin Layer Chromatography}

For the identification of vanillic acid in the presence of vanillin pre-coated silica gel plates (Merck) were used with the following solvent mixture: toluene/chloroform/acetone $(40 \mathrm{ml}+25 \mathrm{ml}+$ $35 \mathrm{ml})$.

Animals

Female albino rats, Wistar breed, weighing $160-220 \mathrm{~g}$ were obtained from 'Tierzuchtfarm Hoffmann, Berlin. The rats were fed with standard diet (Altromin R 10) and tap water ad libitum.

Assay of NADPH-linked aldehyde reductase from brain (ox and rat)

Aldehyde reductase was purified according to TABAKoff and ERwrN (2) up to the column chromatographic step. The crude enzyme thus obtained was used for the determination of the inhibitory constant of vanillin according to LINEIVEA VER and BURK and Hunter and Downs (3). The reductase activity was assayed 
spectrophotometrically. The reaction mixtures used consisted of: crude enzyme protein $\left(0.42 \mathrm{mg} \approx 0.0042 \mathrm{U}^{1}\right.$ ), NADPH (from 13 to $150 \mu \mathrm{mol} / 1)$, 4-nitrobenzaldehyde $(217 \mu \mathrm{mol} / \mathrm{l})$ and phosphate buffer $(0.1 \mathrm{~mol} / 1 ; \mathrm{pH} 7.0)$ in a total volume of $3.0 \mathrm{ml}$. The reaction was started by the addition of the aldehyde. The rate of coenzyme oxidation was observed by following the decrease in absorbance at $\lambda=340 \mathrm{~nm}$ at $25^{\circ} \mathrm{C}$ with a Beckman DK $2 \mathrm{~A}$ spectrophotometer.

\section{Assay procedure of monoamine oxidase}

Rats were decapitated and the tissues (brain, heart and liver) excised and homogenized (Potter-Elvehjem) in chilled isotonic $\mathrm{KCl}(1+9 ; \mathrm{w} / \mathrm{v})$. Homogenates of heart and liver were filtered through 4 layers of cheese cloth before use.

These procedures were performed at $+4^{\circ} \mathrm{C}$. For standard assays $0.5 \mathrm{ml}$ of brain and heart homogenate, respectively, was used whereas liver homogenate was added in a volume not exceeding $0.2 \mathrm{ml}$. If $0.5 \mathrm{ml}$ or more of liver homogenate was used, the recovery of vanillin was not constant.

Reaction mixtures were prepared in $25 \mathrm{ml}$ Erlenmeyer flasks immersed in ice.

The standard assaj' contained in a final volume of $5.0 \mathrm{ml}$ : tissue homogenate; $0.05-1.0 \mathrm{ml}$ of 4-hydroxy-3-methoxy-benzylamine hydrochloride solution (substrate concentration from 0.05 to $1 \mathrm{mmol} / \mathrm{l})$; phosphate buffer $(0.1 \mathrm{~mol} / 1 ; \mathrm{pH} 7.0)$. Samples are incubated for $30 \mathrm{~min}$ at $37^{\circ} \mathrm{C}$ in a Dubnoff shaker under air. The reaction was stopped by the addition of $0.46 \mathrm{ml}$ of $\mathrm{HClO}_{4}(60 \%)$. After centrifugation (for $15 \mathrm{~min}$ at $40,000 \mathrm{~g}$ ) $5.0 \mathrm{ml}$ of the supernatant was taken off and the vanillin formed was extracted into $10 \mathrm{ml}$ of toluene (by shaking for $20 \mathrm{~min}$ ). From a $8.0 \mathrm{ml}$ aliquot of the toluene layer the aldehyde was reextracted into $4.0 \mathrm{ml}$ $1 \mathrm{~mol} / 1 \mathrm{~K}_{2} \mathrm{CO}_{3}$ (by shaking for $5 \mathrm{~min}$ ). After centrifugation the absorbance of vanillin was determined at $345 \mathrm{~nm}$ using a Zeiss PMQ II spectrophotometer. Vanillin is stable in $1 \mathrm{~mol} / 1 \mathrm{~K}_{2} \mathrm{CO}_{3}$ for at least $3 \mathrm{~h}$.

A blank was run with each determination and was prepared by adding $\mathrm{HClO}_{4}$ to the non-incubated assay mixture.

The reaction was linear with time for at least $45 \mathrm{~min}$ and with homogenate concentrations from 10 to $150 \mathrm{mg}$ (brain) and from 10 to $100 \mathrm{mg}$ (liver) wet weight. Under our experimental conditions the recovery of vanillin was $75-76 \%$.

In contrast to the mitochondria-bound monoamine oxidase from brain, heart and liver, the serum monoamine oxidase did not accept 4-hydroxy-3-methoxy-benzylamine as substrate.

For the determination of monoamine oxidase activity in the hypothalamus a slightly modified assay was used: 4-5 hypothalami were pooled and homogenized in $\mathrm{KCl}$ at the same ratio as given above. Only $2.5 \mathrm{ml}$ were used for incubation and further assay (performed with half volumes).

\section{Calculations}

The extinction coefficient $\left(\mathrm{cm}^{2} / \mu \mathrm{mol}\right)$ used was 26.1 for vanillin at $345 \mathrm{~nm}$ in $1 \mathrm{~mol} / 1 \mathrm{~K}_{2} \mathrm{CO}_{3}$. The activity of monoamine oxidase can be calculated as follows (for rat brain homogenate):

$\Delta \mathrm{E}_{345}$ measured $\times 0.185=$ nmoles vanillin formed $/$ minute $\cdot g$ wet weight.

\section{Results}

This method has the following advantages:

In incubation mixtures with 4-hydroxy-3-methoxybenzylamine as substrate for monoamine oxidase the aldehyde (vanillin) is the only product formed. Under our experimental conditions vanillin is not further metabolized, which depends on the fact that vanillin is an inhibitor of the NADPH-linked aldehyde reductase from brain $\left(\mathrm{K}_{\mathrm{I}}\right.$ value: $\left.57 \mu \mathrm{mol} / \mathrm{l}\right)$ and that vanillin is no substrate for the aldehyde dehydrogenase in brain homogenate. Thus, the formation of 4-hy-

1) $1 \mathrm{U} \cong 1 \mu \mathrm{mol} / \mathrm{min}$ droxy-3-methoxy-benzoic acid (vanillic acid) in assays with brain homogenate could not be detected by thinlayer chromatography.

As vanillin does not seem to undergo further enzymic metabolism our method enables us to investigate whether certain drugs, the so-called monoamine oxidaseinhibitors, are really acting only on monoamine oxidase or on other enzymes as well. Some of these "monoamine oxidase-inhibitors" are relatively non-specific and also inhibit other enzyme-catalyzed reactions. The phenylethylhydrazines have also been reported as inhibitors of the NAD+-linked aldehyde dehydrogenase from brain (4). The determination of monoamine oxidase-activity with ${ }^{14} \mathrm{C}$-tryptamine as substrate is based on the extraction and counting of ${ }^{14} \mathrm{C}$ indoleacetic acid (5), which is a product of aldehydedehydrogenase catalyzed reaction. Therefore, given that aldehyde-dehydrogenase is more strongly inhibited by a so-called "monoamine oxidase-inhibitor" than monoamine oxidase itself the results obtained may give rise to misleading interpretations.

An additional advantage of our method is the high extinction coefficient of vanillin at $345 \mathrm{~nm}$ in $1 \mathrm{~mol} / \mathrm{l}$ $\mathrm{K}_{2} \mathrm{CO}_{3}$. This enables us to use relatively low sưbstrate concentrations (less than $50 \mu \mathrm{mol} / \mathrm{l}$ ), which are the same as those used in radiometric procedures.

Our method takes advantage of a spectrophotometric measurement at a higher wavelength $(345 \mathrm{~nm})$. Thus, there are only few substances in the incubation mixture, which could interfere with the absorbance due to vanillin. Of the three possible metabolites in the incubation mixture (4-hydroxy-3-methoxy-benzylamine, vanillin and vanillic acid) only vanillin shows an absorption maximum at $345 \mathrm{~nm}$ at $\mathrm{pH} 11.7$ (see Fig. 1).

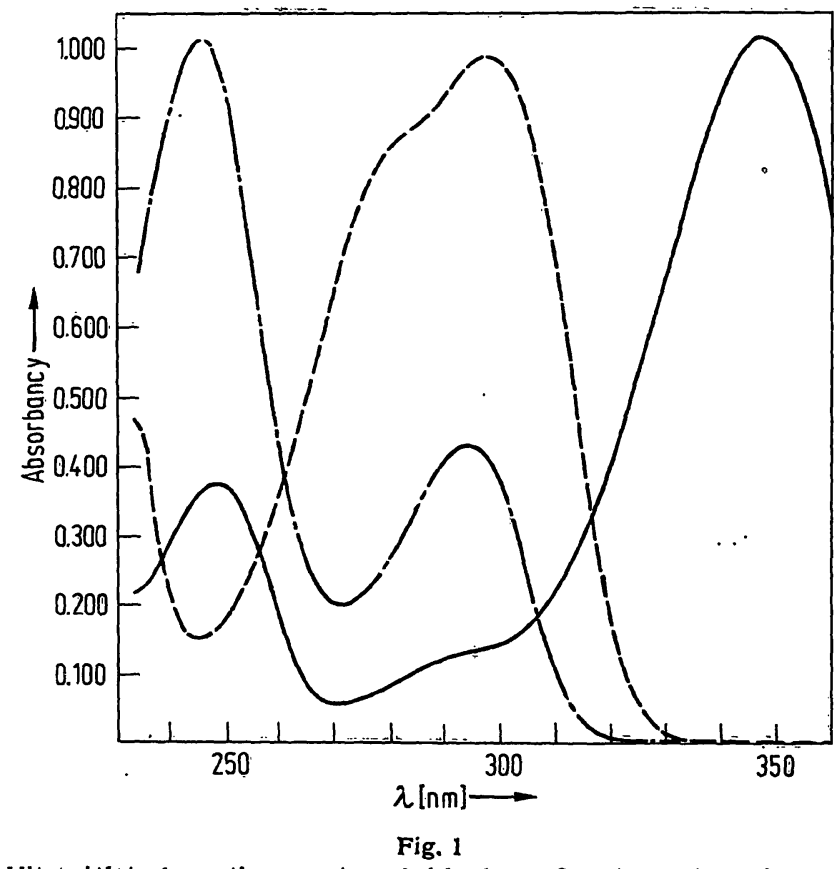

Ultraviolet absorption spectra of 4-hydroxy-3-methoxy-benzaldehyde (vanillin) 4-hydroxy-3-methoxy-benzoic acid (vanillic acid) - - and 4-hydroxy-3-methoxy-benzylamine - $\mathrm{K}_{2} \mathrm{CO}_{2}$ 
$K_{m}$-value and maximal velocity

Under the conditions selected $(0.1 \mathrm{~mol} / 1$ phosphate

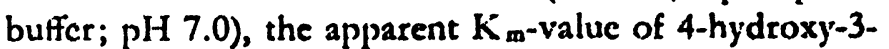
methoxy-benzylamine is 150 to $180 \mu \mathrm{mol} / \mathrm{l}$ for monoamine oxidasc of rat brain. The $\mathrm{K}_{\mathrm{m}}$-values of 5-hydroxytryptamine, noradrenaline and tyraminc for rat and mouse brain monoamine oxidase in air were about 70,250 and $100 \mu \mathrm{mol} / \mathrm{l}\left(\right.$ at $25^{\circ} \mathrm{C}$ and $\mathrm{pH} 7.4$ ) respectivcly (6).

The maximum reaction rate for 4-hydroxy-3-methoxybenzylamine for rat brain monoamine oxidase is about $0.128 \mu$ moles/minute and $\mathrm{g}$ wet weight $(\mathrm{pH} 7.0$ ).

Thesc data suggest that, as a substrate for the monoamine oxidase, 4-hydroxy-3-methoxy-benzylamine can be compared with the physiological biogenic amines.

The effect of $\mathrm{pH}$ on the activity of monoamine oxidase from rat brain with 4-hydroxy-3methoxy-benzylamine as substrate

The effect of $\mathrm{pH}$ on the activity of monoamine oxidase is shown in Figure 2. Activity was measured in the normal way. The substrate concentration was $526 \mu \mathrm{mol} / \mathrm{l}$. The pH optimum with 4-hydroxy-3-methoxy-benzylamine as substrate was found to be at about $\mathrm{pH} 9.0$ (see Fig. 2).

The effect of some inhibitors of monoamine oxidase

The production of vanillin in the assay appeared to follow Michaelis-Menten kinetics with increasing concentrations of the substrate 4-hydroxy-3-methoxybenzylamine. When monoamine oxidase-activity was assayed in brain homogenate of rats which have been injected intraperitoneally with irreversible monoamine oxidase-inhibitors, such as iproniazid $(5 \mathrm{mg} / \mathrm{kg})$, pargyline $(10 \mathrm{mg} / \mathrm{kg})$ and tranylcypromine $(0.2 \mathrm{mg} / \mathrm{kg})$,

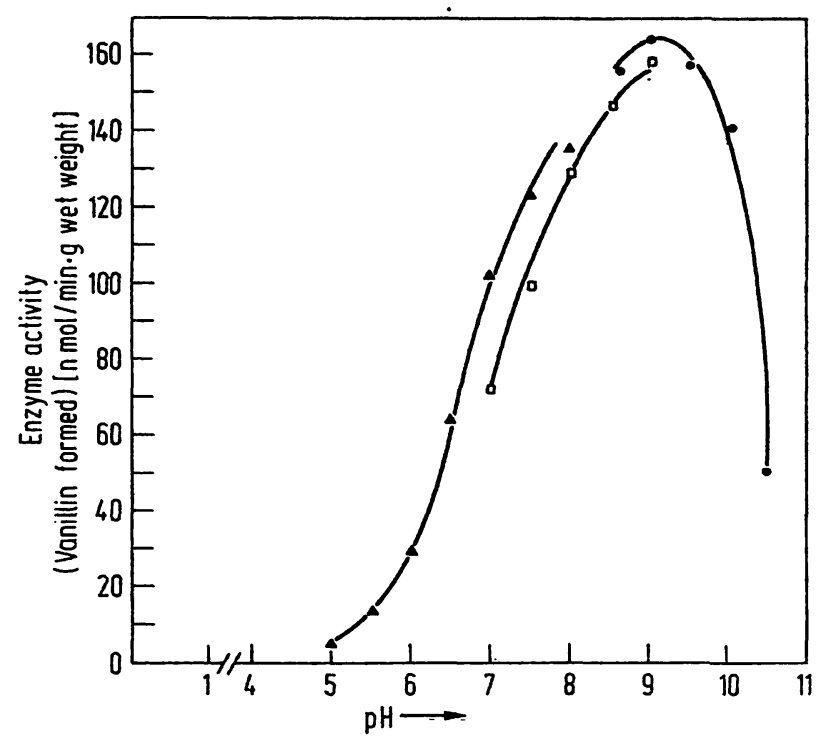

Fig. 2

Effect of $\mathrm{pH}$ on the activity of monoamine oxidase from rat brain with 4-hydroxy-3-methoxy-benzylamine as substrate

The activities of monoamine oxidase were measured at $37^{\circ} \mathrm{C}$. The substrate concentrations used throughout were $526 \mu \mathrm{mol} / 1$. The buffers
used were in all cases 0.1 mol/1. glycinebuffer

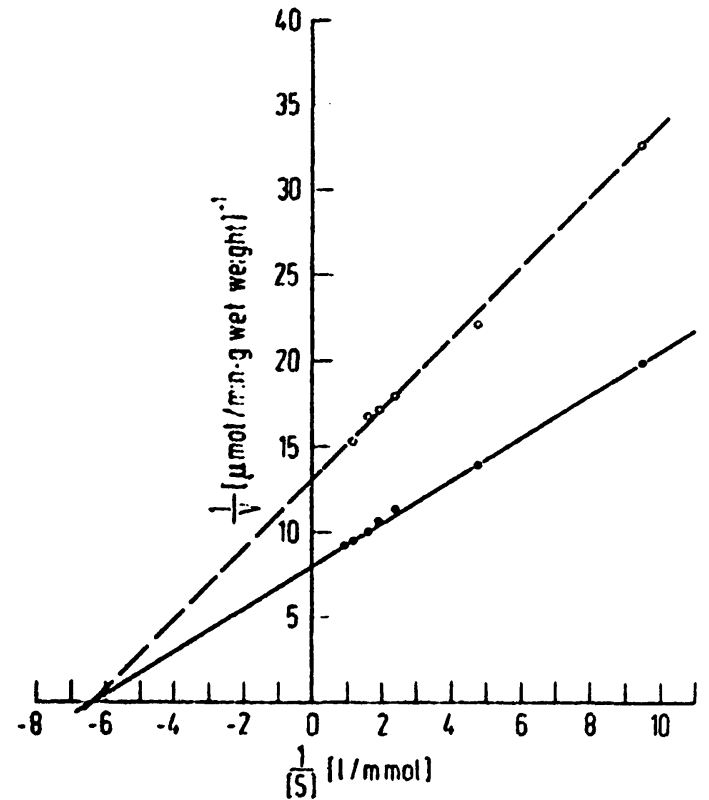

Fig. 3

Double reciprocal plots for 4-hydroxy-3-methoxy-benzyl-amine oxidation by monoamine oxidase from rat brain $\$-0$ reaction without inhibitor: $\mathrm{O}-1-O$ after pretreatment of rats with $0.2 \mathrm{mg} / \mathrm{kg}$ tranylcypromine

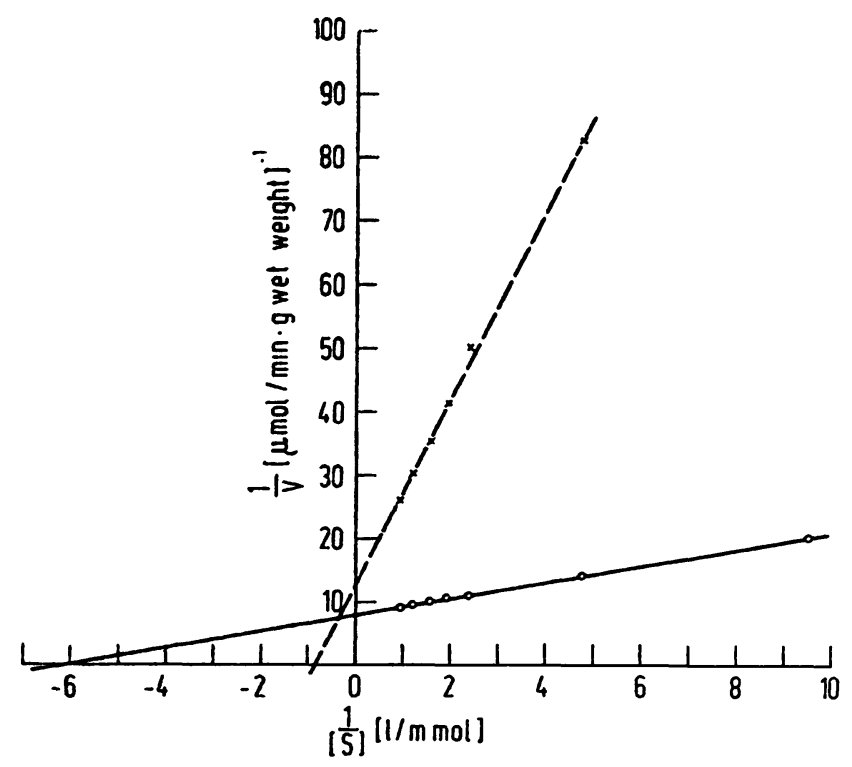

Fig. 4

Double reciprocal plots for 4-hydroxy-3-methoxy-benzylamine oxidation by monoamine oxidase from rat brain. $O-O$ reaction without inhibitor. $x-x$ incubation in the presence of harmaline $(100 \mu \mathrm{mol} / \mathrm{I})$

the inhibition observed appeared to be of non-competitive and mixed-non-competitive type when the data were analyzed according to LINEWEAVER and BuRK (see Fig. 3). When inhibitors such as harmaline and amphetamine $(10 \mathrm{mg} / \mathrm{kg})$ were administered in vivo no inhibition of monoamine oxidase could be found. This finding can probably be explained by the fact that the concentration of substrate in the incubation mixture exceeds the concentration of inhibitor, e. g. the concentration of amphetamine in the brain is about $100 \mu \mathrm{mol} / \mathrm{l}(6)$ after application of $10 \mathrm{mg} / \mathrm{kg}$.

When harmaline was present in the incubation mixture $(100 \mu \mathrm{mol} / \mathrm{l})$ it inhibited the reaction according to a mixed-competitive type (see Fig. 4). 


\section{Discussion}

The attempts to elaborate a simple spectrophotometric assay of monoamine oxidase activity resulted in the introduction of different naturally not occurring amines, e. g. benzylamine (7), m-iodo-benzylamine (8) and $p$-dimethylamino-benzylamine (9). The application of these benzylamines had at least one of the following disadvantages:

1. When these benzylamine-derivatives are used as substrates the absorption maxima of aldehydes produced by monoamine oxidase are below $280 \mathrm{~nm}$. Thus, absorbance due to unprecipitated protein or to substances present in the incubation mixture might interfere with the absorbance of the aldehyde.

2. The turnover of the above mentioned benzylamines is relatively low. Therefore, high substrate concentrations and long incubation times, respectively, must be employed, or incubation must be performed under pure oxygen (1).

3. The further metabolism of the aldehydes is not fully elucidated. The possibility cannot be excluded that subsequent reaction products might interfere with the measurement of aldehy'des.
The 4-hydroxy-3-methoxy-benzylamine presented in this paper as substrate for monoamine oxidase shows not only a great structural similarity to the biogenic phenylethylamines but is also an efficient substrate. The $\mathrm{K}_{\mathrm{m}}$-value is in the same order of magnitude as found for biogenic amines. This substrate is oxidized by monoamine oxidase under air at a high rate, so that low substrate concentrations and incubation times of 20-30 min are sufficient for the assay. The 4-hydroxy3-methoxy-benzaldehyde (vanillin) that is formed as the primary oxidation product is not further metabolized even in crude tissue homogenates. The measurement of this product can be performed at $345 \mathrm{~nm}$. Thus, there are only few substances wich could interfere with the absorbance due to vanillin.

The $\mathrm{pH}$-optimum of non-purified monoamine oxidase from rat brain towards 4-hydroxy-3-methoxy-benzylamine as substrate was found to be at about $\mathrm{pH} 9.0$. This is not an extraordinary value for optimal $\mathrm{pH}$ conditions of monoamine oxidase activity. In 1972, Tirton reported for monoamine oxidase preparations from rat liver a $\mathrm{pH}$ optimum in the same order of magnitude with benzylamine as substrate (10). Mushahwar et al. also found a $\mathrm{pH}$ optimum at $\mathrm{pH} 9.0$ for a microsomal monoamine oxidase-preparation from bovine thyroid using phenylethylamine as substrate (11).

\section{References}

1. GLICK, D. (Ed.), "Analysis of biogenic Amines and their related enzymes." Methods of Biochemical Analysis, Suppl. vol., Interscience Publishers, New York, 1971, pp. 35-87. - 2. TABAKoff, B. \& ERwin, V. G. (1970), J. Biol. Chem. 245, 3263 3268 - 3. Hunter, A. \& Downs, C. E. (1945), J. Biol. Chem. 157, 427-446. - 4. Duncan, R. J. S. \& Tipton, K. F. (1971), Eur. J. Biochem. 22, 257-262. - 5. WurtMan, R. J. \& AxFirod, J. (1963), Biochem. Pharmacol. 12, 1439-1441. - 6. GreEN, A. L. (1970), Biochem. J. 121, 37P-38P. - 7. TABOR, C. W.,
TABOR, H. \& Rosenthal, S. M. (1954), J. Biol. Chem. 208, 645661. - 8. Zeller, V., RaMAChANDER, G. \& ZeLLER, E. A. (1965); J. Med. Chem. 8, 440-443. - 9. Tabakoff, B. \& Alivisatos, S. G. A. (1972), Anal. Chem. 44, 427-428. - 10. Tipton, K. F. (1972), Biochem. J. 128, 913-919. - 11. Mushahiwar, I. K., Oliner, L. \& Schulz, A. R. (1972), Canad. J. Biochem. 50, 1035-1047. - 12. Christ, W. \& Rakow, D. (1973), NaunynSchmiedeberg's Atch. Pharm. Suppl. to vol. 277, R 10.

\author{
Dr. Wolfram Christ \\ Institut für Neuropsychopharmakologie der \\ Freien Universität Berlin \\ 1 Berlin 19 \\ Ulmenallee 30 \\ West-Germany
}

